\title{
THE IMPACT OF THE COVID-19 PANDEMIC ON BUSINESS IN AFRICA: IMPLICATIONS FOR BUILDING AN EU-AU PARTNERSHIP OF EQUALS
}

\author{
JeĻENA ZašČERINSKa ${ }^{1}$, Ludmila AleKSEJeVA ${ }^{2}$, MihaILS ZašČERINSKis ${ }^{3}$, \\ Olga Gukovica ${ }^{4}$, Anastasija Aleksejeva ${ }^{5}$
}

Centre for Education and Innovation Research (Latvia)

\begin{abstract}
The global outbreak of Covid-19 has led to unprecedented changes in people's lives, including business. Higher education serves as a key tool for the preparation of prospective traders and investors in both the European Union and the African Union. The purpose of the present contribution is to analyse the system of the external and internal perspectives for the implementation of cooperation between the European Union and the African Union in higher education underpinning the creation of the model of the process and phases of building a partnership of equals. The research is of a qualitative nature. The empirical study was carried out on 9 November 2020. The data were collected via a focus group interview in the online panel discussion 'Support Business in Africa during Covid times: The Influence of the Corona Crisis'. Seven participants took part in the discussion. The conclusion is that the model for the process of building the partnership of equals is valid. The implications for building the EU-AU partnership of equals are formulated. The limitations of the research are indicated. Directions for further research are proposed.

KEY WORDS: Africa, business, Covid-19, European Union, partnership of equals.
\end{abstract}

JEL CODES: A23, B27, B55, F00.

DOI: http://dx.doi.org/10.15181/rfds.v33i1.2207

\section{Introduction}

The outbreak of Covid-19 in the world has led to unprecedented changes in people's lives. Many people have experienced rapid transformations in many aspects of their lives: working conditions, shopping, travelling, finance, etc. The Covid-19 pandemic is considered to be a crisis (OECD, 2020). Crises can be differentiated as political, economic, social, financial, etc.

\footnotetext{
Jel̦ena Zaščerinska - doctor degree, Centre for Education and Innovation Research, Leading researcher Scientific interests: university-business cooperation

E-mail: iizi.info@inbox.lv

Tel. +37129435142

2 Ludmila Aleksejeva - MA degree, Centre for Education and Innovation Research, Leading researcher Scientific interests: entrepreneurship education

E-mail: asava@inbox.kv

Tel. +37126859183

3 Mihails Zaščerinskis - BA student, Centre for Education and Innovation Research, Leading researcher Scientific interests: tourism studies

E-mail: mihails.zascerinskis@gmail.com

Tel. +371 22303090

4 Olga Gukovica - BA degree, Centre for Education and Innovation Research, Leading researcher Scientific interests: SME development E-mail: srripka@inbox.lv Tel. +37127141434

5 Anastasija Aleksejeva - BA student, Centre for Education and Innovation Research, Leading researcher Scientific interests: teaching English for Business Purposes E-mail: vaset@inbox.lv Tel. +37122367985
} 
As all the dimensions of life in the modern world are interrelated, crises are interdependent, too. That means that a crisis can be a factor in another crisis. The Covid-19 crisis is a cornerstone for the situation of development in the world.

Business in the world, including Africa, has also been significantly adapting to the new situation created by the Covid-19 pandemic.

With a growing population and significant economic potential, Africa has become more of a geopolitical focus (Amare, 2020: 12). The growing competition for influence between the continent's traditional partners and emerging powers, such as China, India and the Gulf states, has given many governments across Africa increasing agency (Amare, 2020: 12). But the EU (European Union) is still the most significant player in Africa in the 'partnership of equals' between the two continents (Amare, 2020: 12).

The EU wants to move away from a donor-recipient dynamic prioritising development, humanitarian and security concerns, towards a more balanced relationship based on trade and investment (Amare, 2020: 12).

Migration, development finance, trade and global health security form the roadmap for EU-AU (African Union) partnership (CGD, 2019). However, the higher education sector is not considered for an EU-AU partnership of equals, despite the fact that higher education plays a crucial role for the development of the business sector (Fife, 2000).

The current Covid-19 crisis has had a two-fold influence on higher education, as is shown in Figure 1:

- on one hand, the crisis has reinforced the value of higher education, as educational attainment has always had a huge impact on employability (OECD, 2013) and social cohesion (The European Council, 2010);

- on the other hand, the crisis has led to the critical importance of expanding access to as many students as possible, increasing the capacity of state institutions to serve students, and refocusing energies on retention and pedagogical research (Galilee-Belfer, 2010).

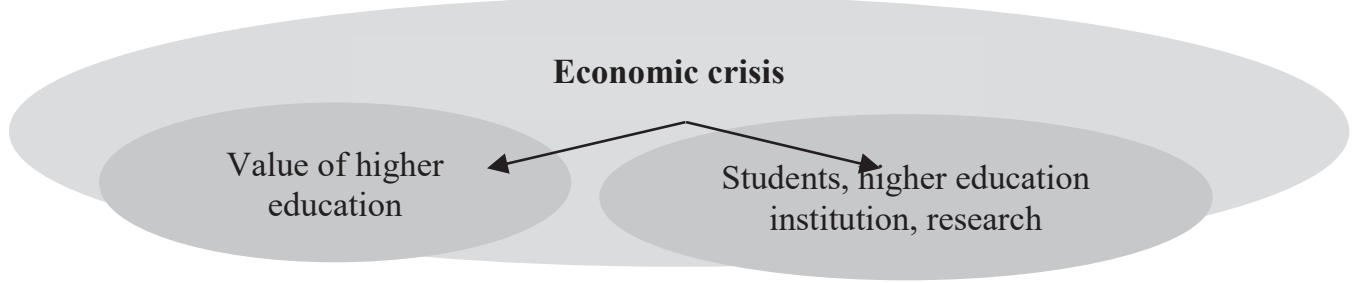

Figure 1. The relationship between economic crisis and higher education

Our analysis of existing literature reveals that different concepts of equality (Dalle Mulle, E, 2016) have been identified by the scientific community as the key concept in a partnership of equality. Further on, factors that on one hand pose barriers to partnership, and on the other hand contribute to the degree of its success, have been determined and explored (Canto, Hannah, 2001). Against this background, the process of building a partnership of equals has not yet been described by the research community.

The scientific problem reflected in the article is put forward: What is the process of building a partnership of equals?

The purpose of the present contribution is to analyse the system of external and internal perspectives for the implementation of cooperation between the European Union and the African Union in higher education underpinning the creation of the model of the process and phases of building a partnership of equals.

The object of the research is the EU-AU partnership of equals.

The tasks of the article include:

- to analyse the system of external and internal perspectives;

- to model the process and phases of building the partnership of equals; 
- to validate the model of the process and phases of building the partnership of equals by carrying out an empirical study;

- to draw conclusions on the model validity;

- to formulate implications for building an EU-AU partnership of equals.

The research methods applied include the use of theoretical and empirical methods.

Theoretical methods imply the analysis of theoretical sources and theoretical modelling.

The empirical study was based on a focus group interview conducted with representatives of both European and African countries. The focus group interview served as the basis for data collection. The present research employs qualitative methodology, or in other words, the course of the research and empirical study as content analysis is a qualitative process (Krippendorff, 2004). A qualitative process is a methodology used mostly in the interpretive approach (Thanh, Thanh, 2015).

\section{Conceptual framework}

Cooperation between the European Union and the African Union is intended to be a 'partnership of equals' (Amare, 2020: 12).

The modelling of the process of building a partnership of equals requires an appropriate methodology, or in other words, the course of the cooperation to be considered.

For building a partnership of equals between the EU and the AU, the System-Constructivist Theory is proposed as the methodological foundation in the present research. The System-Constructivist Theory implies that the world is constructed in modules (Maslo, 2006). The New Constructivism supposes that no understanding is separated from the observer, and a reality is socially constructed that is confirmed by the surrounding people (Maslo, 2006). Constructing is a creative process that includes a variety of meaning understandings to offer a variety of opportunities to construct the development of mankind (Maslo, 2006). The constructive process is always situative (Lamberigts, Dippenbroks, 2004). The cognitive process is regarded to be a component by the Pedagogical Theory of Social Constructivism: perception is not right or wrong, but whether it is relevant to a place or the conditions (Maslo, 2006). The System-Constructivist Theory emphasises that the human being's point of view depends on the subjective aspect:

- everyone has his/her own system of external and internal perspectives. The system of external and internal perspectives is a complex open system (Osberg, 2008; Rudzinska, 2008);

- experience plays the central role in the construction process (Maslo, 2007).

The mechanism of the System-Constructivist is based on the methodology of the system of external and internal perspectives, as is demonstrated in Figure 2.
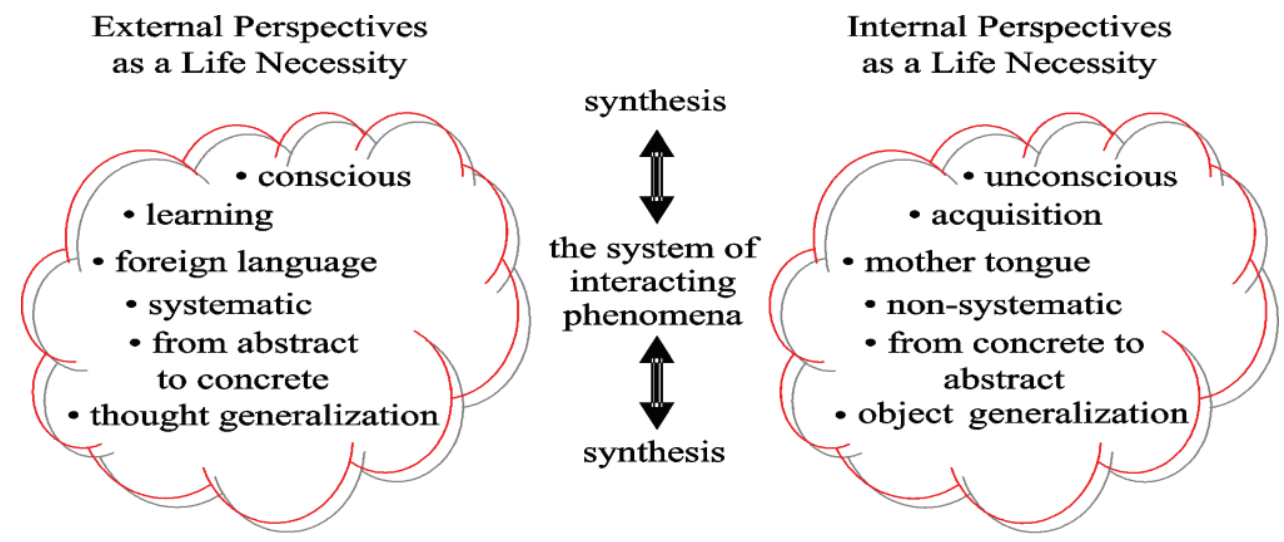

Figure 2. The development of the system of external and internal perspectives 
The development of the system of external and internal perspectives and the sequence of its implementation proceeds:

- from the external perspective;

- through the phase of unity of external and internal perspectives or the system of interacting phenomena;

- to the internal perspective.

The system of external and internal perspectives develops in the social-cultural environment. The sociocultural environment is focused on diverse open problem situations. The socio-cultural environment moves:

- from object-regulation;

- through other-regulation;

- to self-regulation.

The socio-cultural environment is based on the principles of mutual sustainability, complementarity and reflexivity, as is shown in Table 1.

Table 1. Conditions for the development of the system of external and internal perspectives in the socio-cultural environment.

\begin{tabular}{|l|l|l|}
\hline Socio-Cultural Environment \\
\hline External Perspective & Internal Perspective & \multicolumn{2}{l|}{} \\
\hline Interpersonal dialogue & Cultural dialogue & Individual's internal dialogue \\
\hline Object-regulation & Other-regulation & Self-regulation \\
\hline $\begin{array}{l}\text { Establishing social purposes, social } \\
\text { interaction planning and organising }\end{array}$ & $\begin{array}{l}\text { Establishing joint purposes, collabora- } \\
\text { tion planning and organising }\end{array}$ & $\begin{array}{l}\text { Establishing personal purposes, } \\
\text { individual planning and organising }\end{array}$ \\
\hline Social decision making & Joint decision making & Individual decision making \\
\hline External evaluation & Mutual evaluation and self-evaluation & Self-evaluation \\
\hline
\end{tabular}

An analysis of the process demonstrated in Figure 2, and the conditions for the development of the system of external and internal perspectives in the socio-cultural environment presented in Table 1 allow the authors of the article to model the process and the phases of building a partnership of equals as proposed in Figure 3.

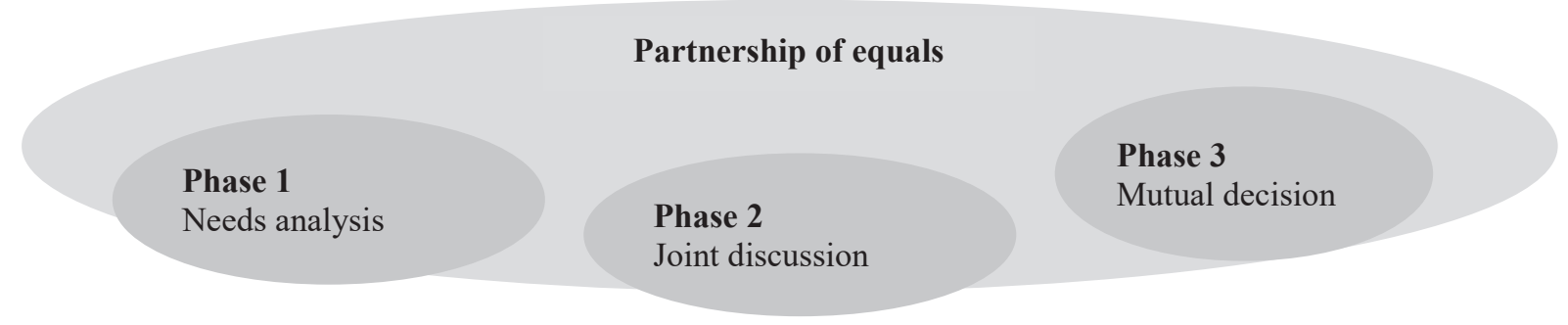

Figure 3. The process and phases of building the partnership of equals in the development of the system of external and internal perspectives

Phase 1 (Needs Analysis) is aimed at a safe environment for all participating parties. The phase is organised in a frontal way, involving all interested parties to participate in their needs' analysis. Phase 2 is 
designed for the participants' analysis of an open problem situation and their search for a solution based on participants' peer-work. Phase 3 emphasises the participants' self-regulation with the use of assessment of the process and self-evaluation of the results. The participants present their self-evaluation at the end of each phase of the process.

\section{Empirical study}

This part of the article consists of the design of the empirical study, the survey results, and the findings of the empirical study.

The design of the empirical study

The design of this empirical study is not innovative, and neither is it meant to be. The strengths are in the researchers' experience, and their ability to use this experience, as well as the data from the focus group interview, to spin a useful tale of the process of building the partnership of equals (Fife, 2000).

The design of the empirical study comprises:

- the purpose and question;

- sample;

- methodology of the study implementation.

The empirical study was aimed at evaluating the impact of the Covid-19 pandemic on selected business sectors in selected countries in Africa.

The empirical study's question was as follows: What is the impact of the Covid-19 pandemic on selected business sectors in selected countries in Africa?

Exploratory research was employed in the empirical study (Phillips, 2006). The exploratory research is aimed at generating new questions and hypotheses (Phillips, 2006). The exploratory methodology proceeds:

- from exploration in Phase 1;

- through analysis in Phase 2;

- to hypothesis/question/implication development in Phase 3.

The interpretive research paradigm was used in the study. The interpretive paradigm features the researcher's interest in a phenomenon. It is characterised by the researcher's practical interest in the research question (Cohen, Manion, Morrison, 2003). The interpretive paradigm is aimed at analysing the social construction of the meaningful reality. Meanings emerge from the interpretation. The researcher is the interpreter.

The present empirical study was carried out on 9 November 2020.

The data were collected via the focus group interview within the online panel discussion 'Support Business in Africa during Covid times: The Influence of the Corona Crisis'.

In total, seven participants took part in the discussion. Participants from three countries, Germany, Uganda and Mali, participated in the focus group interview. The participants represented universities, research institutions, local government, partner country associations, industries and companies, including investing companies. The participation of international respondents from different types of institution in the focus group interview allows the conclusion that the collected data is reliable and valid.

The focus group interview examines how knowledge, and, more importantly, ideas, develop and operate within a given cultural context, and explored exactly how the opinions were constructed (Kitzinger, 1995). A focus group usually includes from five to ten participants (Krueger, 2002). The choice of participants for a focus group interview is conventionally based on three criteria:

- the participant's knowledge on a given topic;

- the participant's cultural difference and educational diversity (scientific direction, occupation, training, etc);

- the hierarchy of participants in the group. 
The number of participants depends on the heterogeneity of the focus group: the greater the heterogeneity of the group, the fewer the number of participants (Okoli, Pawlovski, 2004). Further on, smaller groups show greater potential (Krueger, Casey, 2000) to examine the process of construction of knowledge and opinion.

The sample was represented by:

- a respondent from a German university and a research institution (Respondent 1);

- a respondent from Germany (Respondent 2);

- a respondent from a German private insurance company (Respondent 3);

- a respondent from Uganda (Respondent 4);

- a respondent from a German IT investing company (Respondent 5);

- a respondent from Mali who worked with the president of Mali until the military coup in August 2020 (Respondent 6);

- a respondent from a German university and a research institution who has real business experience of the banking sector (Respondent 7).

All the respondents provided the researchers with informed consent. The focus group interview was video-recorded, and detailed notes were made. The interview was open and exploratory until novel concepts and ideas stopped emerging. Full transcripts of the focus group interview were made, and a thematic analysis was carried out to elucidate common themes and topics in the discussion.

The content of the collected data was analysed. Structuring content analysis assists in categorising the data in accordance with the previously determined criteria (Budde, 2005). In turn, the summarising content analysis seeks to reduce the material in such a way that the essential contents are preserved, but a manageable short text is produced (Mayring, 2004: 269).

The survey results

The respondent from a German university and a research institution (Respondent 1) focused on studies of business and technology in Africa, and pointed out that Germany had decreased investment in Africa by $30 \%$ since the Covid-19 pandemic started. He also emphasised that the Covid-19 pandemic had slowed down cooperation between Africa and Germany to such a level that the pre-pandemic level of cooperation could be restored in ten to 15 years from now. He expressed his wish that, in its efforts to restore the cooperation with Africa to the pre-pandemic level, Germany is supported by Africa.

The respondent from Germany (Respondent 2) commented that inhabitants in Germany do not wish to share their personal and medical data when discussing Covid-19 testing.

The respondent from a private German insurance company (Respondent 3) that deals with exports from Germany to Africa opined that the key point is to promote jobs in Germany, while taking into consideration effects of employment in buyer countries as part of their eligibility. She also highlighted that German companies are under-represented in Africa. Despite the positive developments of a new policy cover in Africa (debt relief for 29 African countries, a slight increase in the number of claims, more applications to the company), $50 \%$ of the projects submitted for realisation between Germany and Africa never materialised. This is a big number in the respondent's opinion. The Covid-19 pandemic slowed down negotiations and projects, affected African buyers' revenue losses, and impacted on investment decisions. Together with these, the credit ratings of Angola, Ghana and Nigeria have been downgraded. Financing has become more expensive. The volume of the new cover of the company, the respondent represented, has decreased, too: the company receives more applications, but with less volume. The respondent expressed the view that export promotion is an important tool for mitigating the effects of the Covid-19 pandemic between Germany and Africa. She proposed to increase the advisory service of the German investment company to be done on site in an African country, to contact the Africa Business Network to support German companies in opening up African markets, to keep the risk stance from before the crisis, to watch developments closely, and to build a supportive ecosystem for stronger coordination between trade promotion and development aid. In conclusion, the respondent expressed her wish to apply a novel approach in comparison with a traditional one while investing 
in Africa. She hoped that the German government would keep tools open for making business. She expected more progress to be made by the German government.

The respondent from Uganda (Respondent 4) belongs to a consultancy company located in Dubai in the United Arab Emirates. She pointed out that more efforts in the Covid-19 pandemic should be invested in the basics in medicine. People in Uganda are not against sharing their personal and medical data. The burden of how to deal with data lies on hospitals. People in Uganda believe in Covid-19, but they live their lives in their great comprehension. The Covid-19 pandemic has an impact on all spheres of life in Uganda. However, the first effect of the coronavirus crisis was not from Covid-19, but was from the lockdowns in Uganda and worldwide. In this Coronavirus crisis time, surprisingly, the oil and gas industries in Uganda are developing. The education sector in Uganda is strongly supported by digital technologies. But digital education in Uganda has had a lot of infrastructural problems and challenges in rural areas. Some institutions use radio, television and computers to reach educational recipients digitally. The opinion of the respondent was that people in Africa understand that they have to move faster. Despite that, in the Covid-19 pandemic, people in Uganda are moving from cities to villages due to the cheaper lifestyle in the countryside. This movement from cities to villages promotes the growth of the villages. However, the villages were not prepared for this increase in the population. For example, many difficulties were experienced by small supermarkets with limited space, staff and products. They had to re-organise their businesses. Due to the coronavirus crisis, the use of renewable energy on an individual level has received much attention. Also, demand for mobile and digital banking services has increased significantly: the World Bank estimated growth by $23 \%$. With regard to investment in Uganda, local investors buy more while international investors sell more. The respondent was aware of heavy checks and bureaucracies in Africa. In comparison with investors from other countries, Chinese investors make fast decisions. She acknowledged the growing role of advice for doing business in Africa. Her opinion was that to find a good advisor is a challenge, funding for good advice is not relevant. A foreign company doing business in Africa permanently has to finance an advisor who is better prepared to run a local business. By the end of the discussion, the respondent suggested investing more in engineering, and particularly in the energy and technology sectors.

The respondent from a German IT investing company (Respondent 5) was positive with regard to the effects of the Covid-19 pandemic on the digital and technological boom in Africa. He assumed that these two sectors have not receive appropriate attention during the last few years, and now they have developed rapidly in a short period of time. These developments increased investing companies' attention to local markets due to the travel restrictions. The respondent was pleased with the number and volume of transactions. However, he pointed out that tickets did not grow at the same time. The respondent considered that the overall situation in investment is even better than in pre-Covid times. In his opinion, food, logistics and service chains have been positively impacted by the two waves of the pandemic. The respondent emphasised that the personal motivation to invest is significant. He viewed personal motivation as marriage, starting a family and bringing up children with a member of the local community in Africa. Another issue highlighted by the respondent was the creation of innovative products for classic investment measures.

The respondent from Mali worked together with the president of Mali until the military coup in August 2020 (Respondent 6). The respondent said that the digital economy in Mali was less impacted by the Covid-19 pandemic. However, she noted that investment in Mali had stopped. In her opinion, the significant decrease in investment in Mali is not due to the pandemic, but because of the military coup in August 2020. She showed that the number of people infected with Covid-19 in Mali is low. Her view was that people in Mali do not take coronavirus seriously. There is no Covid-19 mass testing there. The respondent said that the e-health system in Mali provides very basic access for about $60 \%$ of the country's inhabitants. The penetration of e-money in Africa differs from region to region. With regard to education, the respondent observed that digital education in Mali is still a challenge. In the capital Bamako, the situation is better. The respondent underlined that during only a few years, Mali has experienced seven coups, which have slowed down the country's development. She stressed that Facebook and Twitter were used for organising these coups. Considering issues of investment in Africa by foreign investors, the respondent proposed that is not easy to set 
up a business system in the business environment. Foreign investors should not expect local people to easily accept foreign investment. She described German investors as being pragmatic and direct. She noted that German investors usually say: 'We have, we will do, we expect.' In her view, this does not work with people in Mali. She expressed the wish that German companies share their 'know-how' in technology with representatives of local business. The respondent pointed out that one of the effective ways of sharing is teaching.

The respondent from a German university and research institution, who has real business experience in the banking sector (Respondent 7), expects more women to be involved in business both in Germany and in Africa. He proposed considering opportunities in comparison to risks. In his opinion, a decrease in bureaucracy, in both Germany and Africa, would be beneficial to all.

The findings of the empirical study

The analysis of the data collected through the focus group interview was based on the criterion, namely higher education in the system of external (EU) and internal (AU) perspectives. Table 2 shows the results of the structuring content analysis.

Table 2. The results of the structuring content analysis

\begin{tabular}{|l|l|}
\hline \multicolumn{2}{|l|}{ The system of external and internal perspectives (higher education) } \\
\hline $\begin{array}{l}\text { External perspective } \\
\text { (EU) }\end{array}$ & $\begin{array}{l}\text { Internal perspective } \\
\text { (AU) }\end{array}$ \\
\hline International management (Respondent 1) & Oil and gas industry (Respondent 4) \\
Data management (Respondent 2) & Data management (Respondent 4) \\
Business management (Respondents 3 and 7) & Business management (Respondent 4) \\
Financing (Respondents 3 and 5) & Finance (Respondent 6) \\
Advisory (Respondent 3) & Advisory (Respondents 4 and 6) \\
Digitalisation and technologies (Respondent 5) & Digital and mobile technologies (Respondents 4 and 6) \\
& Engineering (Respondents 4 and 6) \\
\hline
\end{tabular}

The summarising content analysis allows us to identify four business sectors outlined by representatives of both the EU and the AU, namely data management (by two respondents), business management (by three respondents), financing (by three respondents), and digitalisation and technologies (by three respondents). Representatives of both the EU and the AU stressed the need for advisory services to be delivered on site in an African country for foreign investors.

The content analysis allows for the finding that all the respondents discussed their own countries' issues and interests in the light of the Covid-19 pandemic. The discussion lacked the evaluation and development of joint interests and efforts to decrease the impact of the Covid-19 pandemic on business in Africa. This finding is supported by the comment of Respondent 6 that German investors usually say: 'We have, we will do, we expect.' In accordance with the phases in the building of a partnership of equals in the development of the system of the external and internal perspectives shown in Figure 2, the discussion can be related to Phase 1-Needs Analysis.

\section{Conclusions}

The theoretical finding in the present research is the established interrelationships between the building of a partnership of equals and the methodology of the development of the system of external and internal perspectives. Another theoretical finding is the phases of the process of the building of the partnership of equals, as is illustrated in Figure 4.

The empirical finding is that the process of building a partnership of equals in the development of the system of external and internal perspectives relates to Phase 1-Needs Analysis. Another empirical finding is that the Covid-19 pandemic has impacted the European Union and Africa in both ways, namely positively and negatively. 
The positive impact on business in Africa is recognisable in the fields of:

- private insurance;

- the oil and gas industries in Uganda;

- business in the countryside in Uganda;

- the use of renewable energy on an individual level in Uganda;

- mobile and digital banking services in Uganda;

- the digital and technological boom in Africa;

- investing in local markets, transactions in Africa;

- food, logistics and service chains in Africa.

The negative impact on business in Africa is observable in:

- German investment in Africa;

- underrepresented German companies in Africa;

- projects between Germany and Africa;

- African buyers' revenue losses;

- investment decisions in German companies;

- the downgraded credit ratings of Angola, Ghana and Nigeria;

- more expensive financing;

- the new cover of the company;

- German private insurance;

- infrastructural problems and challenges in rural areas of Uganda;

- the e-health system in Mali;

- digital education in Mali;

- the penetration of e-money in Africa.

The empirical finding on the analysis of needs in business in Africa by both the EU and the AU allows for the proposal that the joint efforts of both the EU and the AU in higher education have to be taken into account. The roadmap for an EU-AU partnership of equals in the field of higher education proposes to include an increase in joint study programmes at $\mathrm{BA}, \mathrm{MA}$ and $\mathrm{PhD}$ levels, the exchange of teaching staff, the internalisation of higher education, cooperation in the field of higher education focused on data management, business management, finance, digitalisation and technology, and higher education consulting.

Implications for building an EU-AU partnership of equals are that the process of the building of a partnership of equals proceeds in three phases: from Phase 1-Needs Analysis through Phase 2-Joint Discussion to Phase 3-Mutual Decision. The process should follow this described sequence. If the process misses a phase of the indicated process, the process of the building of a partnership of equals is not complete.

The practical application of the model of the process of building a partnership of equals allows us to draw the conclusion that the model is valid.

The new research has been formulated: what are the criteria, indicators and constructs of building a partnership of equals?

The present research has some limitations. One is the interrelationships between building a partnership of equals between the European Union and Africa and the methodology of the development of the system of external and internal perspectives. The three phases of the process of building a partnership of equals are designed on the basis of the methodology of the development of the system of external and internal perspectives. Another limitation is that the empirical study is based on data collection from only one focus group. The participation of only selected countries from the EU and the AU is also a limitation.

Further research will focus on an analysis of the phases of the interrelationships between the EU and the AU in the process of building a partnership of equals. The search for criteria, indicators and constructs for building a partnership of equals is highlighted. The application of other methods of data collection and data analysis is also proposed. The dataset for further analysis will be extended. The wider involvement of respondents is expected, too. Comparative studies are of great interest in the scientific research community. 


\section{References}

Amare, T. (2020). Africa needs a strategy for Europe. European Centre for Development Policy Management (ECDPM) Great Insights magazine, Vol. 9, Issue 3, p. 12- 13.

Budde, R. (2005). Mexican and Central American L.A. Garment Workers: Globalized Industries and their economic constraints. LIT Verlag Münster.

Canto, I., Hannah, J. (2001). A Partnership of Equals? Academic Collaboration between the United Kingdom and Brazil. Journal of Studies in International Education, Vol. 5, Issue 1, p. 26-41. Doi: 10.1177/102831530151003.

Center for Global Development (CGD). (2019). Building an EU-Africa Partnership of Equals a Roadmap for the New European Leadership. Washington: Center for Global Development.

Cohen, L., Manion, L., Morrsion, K. (2003). Research Methods in Education. London and New York: Routledge / Falmer Taylor \& Francis Group.

Dalle Mulle, E. (2016). A Partnership of Equals or Equal Membership? Equality and Difference in Multinational States. In L. Greenfeld (ed.). Globalisation of Nationalism: The Motive-Force Behind Twenty-First Century Politics, Colchester: ECPR Press, p. 43-68.

Fife, J. (2000). What Business Wants from Higher Education. The Journal of Higher Education, Vol. 71(1), p. 114-116. Doi: $10.2307 / 2649288$.

Galilee-Belfer, M. (2010). Higher Education and the New Economy: Crisis or Opportunity? Summary and Recommendations. The University of Arizona College of Education.

Kitzinger, J. (1995). Education and debate Qualitative Research: Introducing focus groups. British Medical Journal, Vol. 311, p. 299-302.

Krippendorff, K. (2004). Content Analysis. An Introduction to its Methodology. London: SAGE Publications.

Krueger, R. A. (2002). Designing and Conducting Focus Group Interviews. USA: University of Minnesota.

Krueger, R. A., Casey, M. A. (2000). Focus Groups: a Practical Guide for Applied Research. 3rd ed. Thousand Oaks, CA: Sage Publications.

Lamberigts, R., Dīpenbroks, J. V. (2004). Aktīvās mācības kooperatīvā mācību vidē: eksperimenta īstenošana un rezultāti. [Active learning in cooperative learning environment: conducting of an experiment and its results]. Kooperatīvā mācišsanās, p. 106-116. Rīga: RaKa.

Maslo I. (2006). No zināšanām uz kompetentu darbību [From knowledge to competent activity]. Latvijas Universitātes Akadēmiskais apgāds, p. 148-161.

Maslo, E. (2007). Transformative Learning Space for Life-Long Foreign Languages Learning. In D. Cunningham, D. Markus, J. Valdmanis [u.c.] (eds). International Nordic-Baltic Region Conference of FIPLV Innovations in Language Teaching and Learning in the Multicultural Context, 15-16 June, 2007, Latvia, Rīga: Izglītības soli. CD-ROM, p. 38-46.

Mayring, P. (2004). Qualitative Content Analysis. In: U. Flick, E. von Kardoff, I. Steinke (eds.). A Companion to Qualitative Research, p. 266-269. UK, Glasgow: SAGE.

Organisation for Economic Co-operation and Development (OECD). (2020) The COVID-19 Crisis in the Western Balkans: Economic impact, policy responses, and short-term sustainable solutions. Available on line: https://www. oecd.org/south-east-europe/COVID-19-Crisis-Response-Western-Balkans.pdf.

Okoli, C., Pawlovski, S. (2004). The Delphi Method as a Research Tool: an example, design considerations and applications. Information and Management, Vol. 42(1), p. 15-29.

Osberg, D. (2008). Education, Emergence and the Idea of "Non-Normative Normativity". The European Conference of Educational Research, 10-12th September 2008, Gothenburg, Sweden, p. 1-7.

Phillips, D. (2006). Comparative Education: method. Research in Comparative and International Education, Vol. 1, No. 4, p. 304-319.

Rudzinska, I. (2008). The Quality of Aim Setting and Achieved Results in English for Specific Purposes Study Course in Lecturers and Students' Opinion. ATEE Spring University Conference Teacher of the 21st Century: Quality Education for Quality Teaching, May 2-3, 2008. Riga: University of Latvia. Available on line: http://www.ppf.lu.lv/pn/ dalibnieki-results_ab.php [30.04.2008], p. 1-8.

Thanh, N. C., Thanh, T. T. L. (2015). The Interconnection Between Interpretivist Paradigm and Qualitative Methods in Education. American Journal of Educational Science, Vol. 1, No. 2, p. 24-27.

The European Council by the Reflection Group on the Future of the EU 2030 Project Europe 2030 Challenges and Opportunities. (2010). Luxembourg: Publications Office of the European Union.

The Organisation for Economic Co-operation and Development (OECD). (2013). Education Indicators in Focus. OECD Publishing. 


\section{COVID-19 PANDEMIJOS POVEIKISAFRIKOS VERSLUI, KAIP TAI PAVEIKS ES IR AS ŠLLU LYGIAS GALIMYBES PUOSEL E JANT PART NERYSTE}

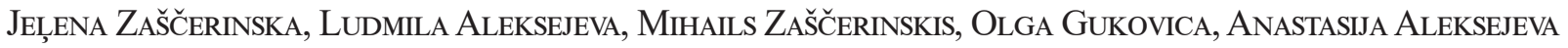
Edukologijos ir inovacinių tyrimų centras (Latvija)

\section{Santrauka}

Visuotinis COVID-19 protrūkis lèmė precedento neturinčius pokyčius žmonių gyvenime, ịskaitant verslą. Aukštasis mokslas yra ta vieta, kur rengiami būsimieji prekybininkai ir investuotojai Europos Sajungoje bei Afrikos Sajungoje. Straipsnio autoriai analizavo Europos Sajungos ir Afrikos Sajungos bendradarbiavimo aukštojo mokslo srityje išorinių ir vidinių perspektyvų galimybes, remdamiesi atlikto tyrimo rezultatais, numatė šalių partnerystės procesą ir lygių galimybių užtikrinimo etapus. Atliktas kokybinis tyrimas. Empirinis tyrimas atliktas 2020 m. lapkričio mėnesį. Duomenys rinkti atliekant interviu su bandomosiomis grupèmis internete, dalyvaujant diskusijoje „Palaikykite verslą Afrikoje COVID laikotarpiu - esant koronaviruso krizei“. Diskusijoje dalyvavo septyni dalyviai. Sukurtas lygiomis teisėmis pagrịstas aukštojo mokslo partnerystės puoselejjimo proceso modelis. Numatytos ES ir AS lygių galimybių asmenų partnerystės pasekmės. Nurodyti tyrimų apribojimai. Pasiūlytos tolesnių tyrimų kryptys.

PAGRINDINIAI ŽODŽIAI: Afrikos Sajunga, verslas, COVID-19, Europos Sajunga, partnerysté.

JEL KLASIFIKACIJA: A23, B27, B55, F00.

Received: 2020-11-30

Revised: 2020-01-15

Accepted: 2020-01-25 